\title{
A Tullock Index for assessing the effectiveness of redistribution
}

\author{
Luke Petach ${ }^{1}$
}

Received: 3 December 2021 / Accepted: 28 January 2022 / Published online: 14 February 2022

(c) The Author(s), under exclusive licence to Springer Science+Business Media, LLC, part of Springer Nature 2022

\begin{abstract}
I propose two alternative versions of a "Tullock Index" for assessing the effectiveness of income or wealth redistribution. In the spirit of Atkinson's (J Econ Theory 2:244-263, 1970) inequality index, the Tullock Index is constructed with reference to either (A) the maximum inequality reduction attainable with current transfer spending or (B) the minimum transfer spending necessary to achieve current post-transfer inequality. Using Current Population Survey (CPS) microdata from 1988 to 2014, I construct annual estimates of the Tullock Index at the national level for the United States. The Tullock Index is increasing over that period, suggesting that redistribution has become less effective in reducing inequality. State-level panel fixed-effects estimates show that ineffective redistribution is related to higher state-level poverty rates, lower employment-to-population ratios, and lower levels of overall employment.
\end{abstract}

Keywords Inequality $\cdot$ Gordon Tullock $\cdot$ Public choice $\cdot$ Redistribution

JEL Classification B31 · D72 $\cdot$ H11 $\cdot$ H21

\section{Introduction}

Is transfer spending effective at reducing inequality? Economists in the public choice tradition historically regard with suspicion attempts to rely on government to redistribute income or wealth. In particular, public choice theory argues that governmental attempts at redistribution likely are to be in service of special interest groups, rather than promoting the general welfare by adopting targeted reductions in poverty or inequality. Tullock (1983a, pp. 173-178) argues that "[A] great many programs purport to be aimed at helping the poor, but actually are aimed at helping someone else-someone who is politically more influential... [B] asically, the modern redistributive state transfers money back and forth within the middle class on the basis of the power of political organization and public misinformation." Despite such justified suspicion, governments around the world are successful at achieving significant reductions in inequality through tax and transfer systems.

Luke Petach

luke.petach@belmont.edu

1 Jack C. Massey College of Business, Belmont University, Nashville, TN, USA 


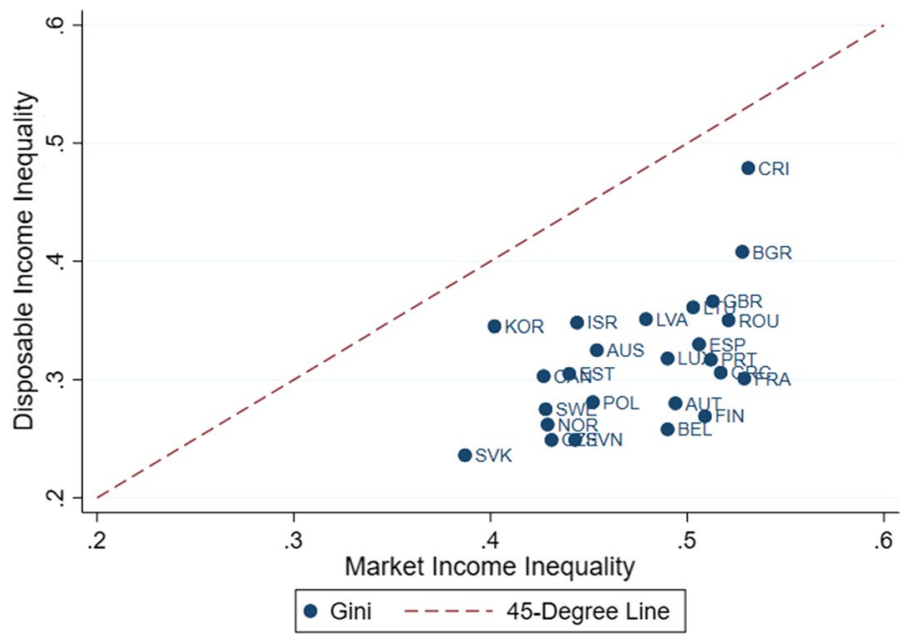

Fig. 1 Disposable income inequality versus market income inequality. Notes Data from OECD Income Distribution Database. "Market Income Inequality" reports the pre-tax and transfer Gini coefficient. "Disposable Income Inequality" reports the post-tax and transfer Gini coefficient

Figure 1 plots Gini coefficients for market income (pre-tax and transfer) and disposable income (post-tax and transfer) for 25 OECD countries: every single observation lies below the 45-degree line, suggesting that at least some redistribution does more than "move money back and forth between the middle class".

The question for the public choice theorist thus becomes, how much of the current pattern of income redistribution is effective-insofar as it reduces poverty or inequality in a targeted fashion in line with its purported justification - and how much represents benefits granted to special interest groups? To answer that question I propose two alternative versions of a "Tullock index" for assessing the effectiveness of redistribution. In the spirit of Atkinson's (1970) inequality index, ${ }^{1}$ the Tullock index is constructed with reference to either (A) the maximum inequality reduction attainable with current transfer spending, or (B) the minimum transfer spending necessary to achieve current post-transfer inequality. Deviations from either of those ideals represent ineffectiveness in the transfer system, insofar as its purported justification is an egalitarian one. Using Current Population Survey (CPS) microdata from 1988 to 2014, I construct annual estimates of the Tullock Index at the national level for the United States. Over that period, the Tullock Index is increasing, suggesting that redistribution has become less effective at reducing inequality. At the state level, results from simple panel fixed-effects models suggest that-for a given level of transfer spending - ineffective redistribution (as measured by the Tullock index) is

\footnotetext{
1 The Atkinson (1970) Index is constructed with reference to the concept of equally distributed equivalent income, $y_{\text {ede }}$. For a given social welfare function $y_{\text {ede }}$ measures the level of income per-head which-if equally distributed-would give the same level of social welfare as the present distribution. Denoting $\mu$ as the mean of the actual income distribution, the Atkinson (1970) index may be written: $I=1-\frac{y_{e d e}}{\mu} . I$ expresses the share of total income that is "wasted" with respect to the attainment of a given level of social welfare. For a value of $I=0.3$ the same level of social welfare could be attained with $30 \%$ less income, provided it were equally distributed. The two versions of the Tullock Index constructed in this paper are interpreted in a similar fashion (the \% of either current transfers or inequality that are "wasted").
} 
associated with a higher poverty rate, a lower employment-population ratio, and reduced total employment.

The rest of the paper is organized as follows. Section 2 briefly reviews some of the myriad reasons for redistribution offered in the literature and compares them to the political economy theory of equilibrium redistribution offered by Tullock (1981). Section 3 introduces the data, discusses the construction of the Tullock index, and examines trends at the national level. Section 4 presents results from state-level panel data models. Section 5 concludes.

\section{Reasons for redistribution}

\subsection{Normative reasons}

Economic justifications for redistribution are rooted in one of several alternative (although not mutually exclusive) rationales: (1) other-regarding preferences and neighborhood effects (Friedman, 1962; Hochman \& Rogers, 1969; Tullock, 1983a), (2) externalities in production (Marglin 1963; Thompson, 1974; Hendrickson et al., 2018; Petach \& Tavani, 2019), and (3) constitutional considerations (Buchanan, 1976; Buchanan \& Tullock, 1962; Wessels, 1993). ${ }^{2}$

Beginning with Hochman and Rogers (1969), several scholars contend that "Pareto optimal redistribution" is consistent with other-regarding preferences. If agent j's income enters as a positive argument into agent i's utility function, it is straightforward to show that some level of redistribution will be Pareto optimal, provided that the utility function is concave and inequality in earnings is sufficient. Similarly, Friedman (1962) points out that if agents obtain positive utility from charitable giving, such giving will be underprovided by the market mechanism. Intuitively, an isolated individual i makes monetary gifts, $\mathrm{g}$, until the marginal benefit of giving equals the marginal cost (assumed to be one dollar): $M B_{i}(g)=1$. With decisions taken collectively, the individual will give until the marginal benefit of giving equals his or her cost share, $1>\alpha_{i}>0: M B_{i}(g)=\alpha$. Summing across all individuals: $\sum_{i} M B_{i}(g)=1$. Comparison of the collective solution with the individual solution reveals charitable giving as a special case of Samuelson's (1954) conditions for optimal public goods provision. Charitable giving also has the property of being "superoptimal" in that a gift increases the utility of both the donor and the recipient.

Even if preferences are purely self-regarding, some redistributive taxation may be optimal if production generates externalities. Thompson (1974) and Hendrickson et al. (2018) argue that if wealth accumulation imposes costs on the public-e.g., in the form of required outlays on national defense-some optimal interior level of capital or wealth taxation exists. Similarly, in a series of studies, Petach and Tavani $(2019,2022)^{3}$ show that if production is characterized by strategic complementarities, an optimal tax and transfer scheme exists that both reduces inequality and increases the level of economic activity relative to their equilibrium values.

\footnotetext{
${ }^{2}$ Redistribution has also been justified by appeals to diminishing marginal utility of income (e.g., see Lerner 1944; Friedman 1947), but such a justification requires the sort of interpersonal comparisons of utility rejected by modern welfare economics. Lionel Robbins (1938) is responsible for providing the modern critique of interpersonal utility comparisons.

3 Also see Tavani and Petach (2021).
} 
Even when preferences are purely self-regarding and no externalities in production are present-such that "political redistribution" of the sort mentioned above is sub-optimalredistribution may be justified from a constitutional perspective. Buchanan (1985) emphasizes such redistribution as distinct in its contractarian character. Buchanan's (1985, p. 248) key insight regarding constitutional redistribution is that changes in the "rules of the game" that govern market interactions may result in different end-state patterns of distributiondespite not targeting those end-states directly—-thereby "embodying interpersonal transfers that might be loosely described as redistibutional." Buchanan and Tullock's (1962) discussion of the perceived insurance value of redistribution behind the Rawlsian veil of ignorance provides one example of the possibility of constitutional justifications for redistributive policy.

\subsection{Equilibrium redistribution}

In contrast to attempts to rationalize redistribution, public choice theory concerns itself with analyzing the self-interested motives for redistribution and how those motives interact with the political process to produce an equilibrium set of redistributive policies. Tullock (1983b, p. 28) asserts the three primary motivations for redistribution are "the desire to receive transfers, charity, and envy", emphasizing "the desire to receive transfers" as primary. While Tullock acknowledges that charitable sentiment plays some role in determining the equilibrium level of redistribution, he rejects the notion that egalitarian motives can explain all, or even most, of the income redistribution observed in reality. In particular, Tullock $(1981,1986)$ argues that egalitarian justifications for redistribution are inconsistent with the paltry sums transferred from the United States and other advanced economies to the developing world: "[S]tandard explanations for egalitarian behavior do not fit the real world. Those Americans who are receiving grants of various sorts from the American government on the grounds that they are poor are uniformly higher in income than the world average" (Tullock, 1986, p. 47). If redistribution truly were explained by egalitarian motives, then "American citizens' income should be reduced by an immense degree" (Tullock, 1981, p. 282). That such is not the case suggests that "[W]e should recognize that our motives in objecting to this are simply selfish. We want to keep our living standards up and we are willing to let people die in southern India to that end" (ibid., p. 280).

Given Tullock's suspicion of egalitarian motives as an explanation for equilibrium redistribution, it is no surprise that his evaluation of the desirability of actual redistribution is negative: "[W]hat we observe is a feeling that a certain amount of income equalization in the United States is desirable (or at least desirable to advocate it), together with an incoherent set of reasons for such redistribution.... [M] ost of the transfers in most societies, democratic or dictatorial, do not go to the poor. They go to people who for one reason or another are politically well organized" (Tullock, 1986, pp. 57-59). Tullock (1981, pp. 288-289) provides a laundry list of examples of policies that redistribute income ineffectively: "The farm program, high wages of civil servants ... the development of human capital at a subsidized rate for people whose natural talent is such that they would already have a higher income than average even without this capital, the price controls which have the purpose of transferring large amounts of wealth from American owners of oil wells to Arab Sheiks and American consumers are all examples." The logic behind how the desire to receive transfers interacts with the political process to produce an ineffective set of equilibrium transfers is illustrated in Tullock's (1959) analysis of the problem of funding access roads in a simple majority voting system. 
Tullock (1959, p. 573) considers a case of "a township inhabited by one hundred farmers who have more or less similar farms is cut by a number of main roads maintained by the state." The township builds and maintains the local roads that connect to the main highway(s); outlays on local road maintenance are decided by majority rule voting with logrolling. Should each farmer follow a purely self-interested voting plan, Tullock (1959, p. 575) argues that.

the outcome is clear. Each farmer would enter into bilateral agreements with enough farmers on other roads to insure that his own was repaired. He would then be forced to count as part of the cost of getting his road repaired the cost (to him) of repairing the roads of the other 50 farmers. These bilateral agreements, however, would overlap. Farmer A (more precisely the farmers on road A) would bargain with Farmers B, ..., M. Farmer M, on the other hand, might make up his majority from Farmer A and Farmers N, ..., Z.

In the aggregate, the result of that pattern of bilateral agreements would be excess redistribution in the form of road maintenance expenditures: "[T]he natural result would be that each road would be maintained at a level considerably higher and at greater expense than is rational from the standpoint of the farmers living along it. Each individual behaves rationally, but the outcome is irrational" (Tullock, 1959, p. 575). Considering Tullock's work in toto, the conclusion of the public choice approach is clear: equilibrium redistribution in a democracy is unlikely to be effective at reducing inequality.

The theoretical discussion thus far appears to be at an impasse. Despite the fact that many possible rationalizations for redistribution are possible, public choice theory offers clear reasons to suspect that redistributive policy will be ineffective at reducing inequality in equilibrium. Whether redistribution functions in line with the justifications offered above or merely as a device to transfer income to politically well-organized groups is therefore an empirical question.

\section{Data and methodology}

The primary data herein are retrieved from the Integrated Public Use Microdata Series (IPUMS) of the Current Population Survey's (CPS's) Annual Social and Economic Supplement (ASEC), for the years 1988 to 2014 (Flood et al., 2020). The sample is restricted to that period because it is the longest time horizon in the IPUMS CPS data over which the component variables of total pre-tax personal income remained unchanged, making it possible to break total personal income into its "market income" and "transfer income" components in ways that are comparable across years. ${ }^{4}$ Market income is calculated as the sum of wages and salaries, business income, farm income, retirement income (excluding social security and Veterans Administration benefits), interest income, dividend income, rental income, and "other" income, which includes small amounts received from sources such as hobbies or severance pay. Transfer income is calculated as the residual of total income remaining after deducting the calculated value of market income (such that total income $=$ transfer income + market income); it includes social security income, income

\footnotetext{
4 All dollar values are converted to constant 1999 dollars using the Bureau of Labor Statistics' Consumer Price Index (CPI).
} 
from various public assistance programs commonly referred to as "welfare", 5 supplemental security income, unemployment insurance income, and income from educational assistance. Table 4 in Appendix 1 provides a detailed description of both income concepts and their component parts.

After market income and transfer income have been calculated, I construct estimates of two versions of a Tullock index in the following fashion. I assume that the goal of redistributive policy is to achieve the largest possible reduction in inequality at the least cost. While I acknowledge that other possible reasons for redistribution are possible (e.g., internalizing spillovers in production or satisfying a contextually specific normative goal), the foregoing assumption is characteristic of much contemporary debate over redistribution. I refer to it as the egalitarian assumption. Taking the egalitarian assumption as the criterion for effective redistribution, each version of the Tullock index is constructed to capture deviations from that baseline.

Version $\mathbf{A}$ of the Tullock index measures deviations from the egalitarian assumption by calculating the maximum possible inequality reduction attainable with current levels of transfer spending under a lump-sum transfer policy and comparing that value to the actual level of post-transfer inequality. To begin, denote the actual level of current post-transfer inequality by $G$ (measured by the Gini coefficient for total personal income). Denote the counterfactual level of inequality by $\widehat{G}$. To arrive at $\widehat{G}$, I calculate the total amount of current transfer spending by summing transfer income across all individuals in the IPUMS's CPS data for a given year, denoting that value by $T$. I then construct an income counterfactual wherein all households with market incomes below the median receive a lump-sum transfer equal to $\frac{T}{n_{m}}$, where $n_{m}$ is the number of households with market incomes less than the median $\left(\overline{y_{m}}\right)$; households with market incomes above the median receive no transfers. For an individual, $i$, with market income, $y_{m}^{i}$, counterfactual income, $\widehat{y^{i}}$, thus is given by:

$$
\widehat{y^{i}}= \begin{cases}y_{m}^{i}+\frac{T}{n_{m}} & \text { if } y_{m}^{i}<\overline{y_{m}} \\ y_{m}^{i} & \text { if } y_{m}^{i} \geq \overline{y_{m}}\end{cases}
$$

Counterfactual $\widehat{G}$ is then calculated as the Gini coefficient for $\widehat{y^{i}}$. More important, fixing the value of $T$ ensures that $\widehat{y^{i}}$ is a mean-preserving transformation of total personal income. To illustrate the magnitude of the difference in inequality implied by the income counterfactual, Fig. 2 plots the Gini coefficient for market income, post-transfer income, and counterfactual income over the sample period.

Given $\widehat{G}$, version $\mathbf{A}$ of the Tullock index is given by:

$$
\text { Tullock }_{A}=1-\frac{\widehat{G}}{G}
$$

Assuming that $\widehat{G}<G$, the Tullock index has an interpretation like the Atkinson (1970) index. Specifically, Tullock $k_{A}$ indicates the amount of inequality that is "wasted" or "ineffective", given the current level of transfer spending and the egalitarian assumption. For a hypothetical value of Tullock $_{A}=0.2$, the index indicates that the actual level of inequality could be $20 \%$ lower with current transfer spending, should current

\footnotetext{
${ }^{5}$ For instance, Aid to Families with Dependent Children, Aid to Dependent Children, General Assistance Program, Emergency Assistance, and Cuban/Haitian Refugee and Indian Assistance.
} 


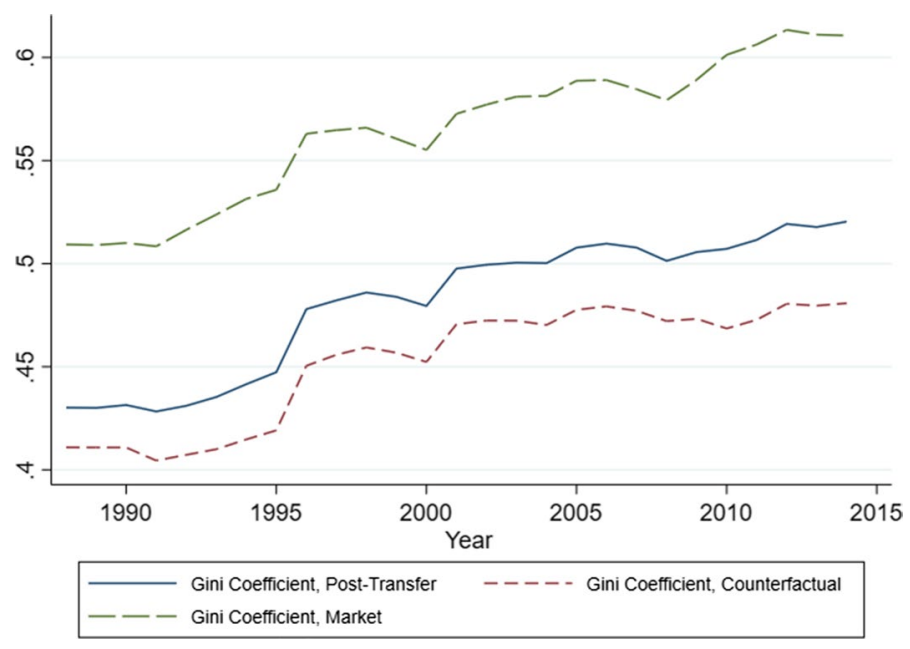

Fig. 2 Market, post-transfer, and counterfactual income inequality

spending be given in equal-sized per-capita lump-sum transfers to individuals with market incomes below the median.

Version $\mathbf{B}$ of the Tullock index measures deviations from the egalitarian assumption by calculating the minimum per-capita lump-sum transfer necessary to achieve the current level of post-transfer inequality. Denote total current transfer spending again by $T$. To calculate the counterfactual level of transfer spending, $\widehat{T}$, I adopt the following procedure. First, to maximize the inequality reduction attained from a given amount of transfer spending I assume that only individuals with below median market income receive transfers under the counterfactual. Second, I calculate the initial per-capita value of transfers received by all individuals with market incomes less than the median and add that amount to their initial market income. The initial value of counterfactual income for individuals with market incomes below the median is given as $\widehat{y^{i}}=y_{m}^{i}+\frac{T_{L}}{n_{m}}$, where $T_{L}$ is the sum of all transfers initially given to individuals with below-market incomes, such that $\frac{T_{L}}{n_{m}}$ is the initial per-capita amount transferred to such individuals. For individuals with above-median market incomes, counterfactual income is simply set equal to their current market income. I solve numerically for $\widehat{T}$ by iteratively increasing the per-capita transfer to individuals with below-median market incomes until the Gini coefficient for counterfactual income converges to the Gini coefficient for current posttransfer income. $\widehat{T}$ simply is the per-capita transfer under the counterfactual multiplied by the number of individuals receiving the transfer. Given the counterfactual level of transfers, the Tullock index is calculated as:

$$
\text { Tullock }_{B}=1-\frac{\widehat{T}}{T}
$$

In that form, the index indicates the percentage of current transfers that is "wasted" or "ineffective" with respect to the attainment of a given level of inequality. A hypothetical value of Tullock $_{B}=0.1$ would suggest that the current level of inequality could be attained with $10 \%$ less transfer spending. To illustrate the magnitude of the difference 


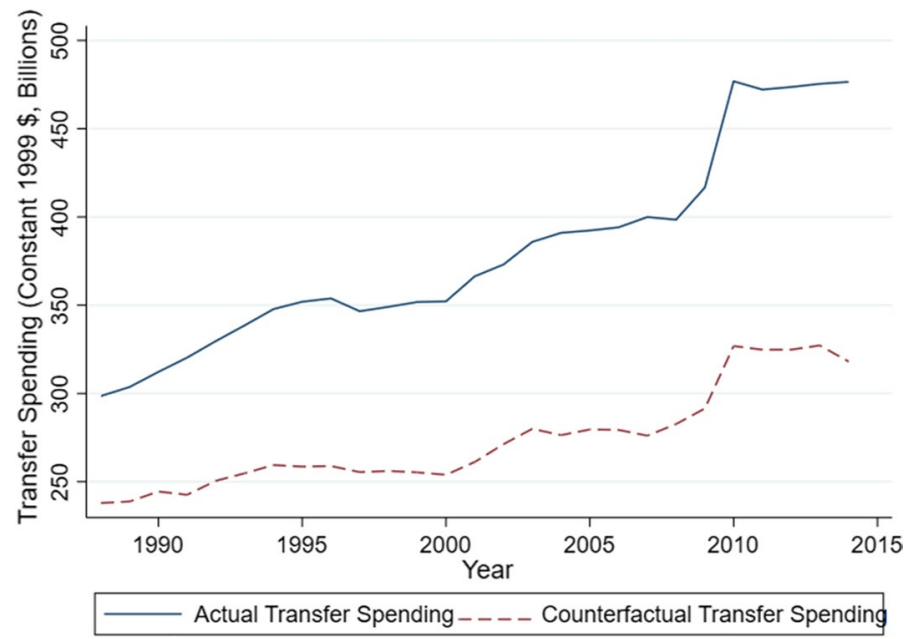

Fig. 3 Transfer spending

in transfers implied by the counterfactual, Fig. 3 plots actual and counterfactual transfer spending over the sample period.

Before examining trends in each version of the Tullock index over time, a few caveats are in order. First, it is likely that the data analyzed here understate the true amount of transfers. Because the income concepts in the IPUMS CPS focus on pre-tax income, the versions of the Tullock index I've constructed miss any redistribution that happens through the tax system. From the perspective of a critic of redistribution like Tullock, that omission is unfortunate: many tax credits and deductions are precisely the kinds of movement of money back and forth between the middle class that Tullock derided. ${ }^{6}$ Similarly, the values calculated here leave out some important transfers-in-kind, such as the Supplemental Nutritional Assistance Program (SNAP). The data also omit the values of implicit transfers that occur through other public policies such as import tariffs. Second, because I restrict the sample to individuals 18 and older, some transfers to children will be missed. Finally, even though lump-sum transfers are efficient from a welfare perspective-i.e., when compared to other tax-and-transfer arrangements-lump-sum transfers may nonetheless generate negative income effects (assuming that leisure is a normal good), resulting in the dissipation of a portion of the "rents" received through the transfer program. Lump-sum transfers themselves may therefore be "wasteful", despite not altering household incentives on the margin. That observation suggests that an additional possible interpretation of the Tullock index is as a comparison of one really "wasteful" transfer system (e.g., proportional or progressive subsidies) with a less "wasteful" transfer system (lump-sum payments).

For each of the above caveats, the implication of either (A) underestimating the total volume of transfers or, (B) overestimating the efficiency of lump-sum transfers, is that the Tullock index probably understates the true amount of ineffectiveness in the current transfer system. Both versions of the index should therefore be interpreted as lower bounds on the amount of ineffective transfer payments.

${ }^{6}$ It is well known, for example, that the mortgage interest income tax deduction is quite regressive. 


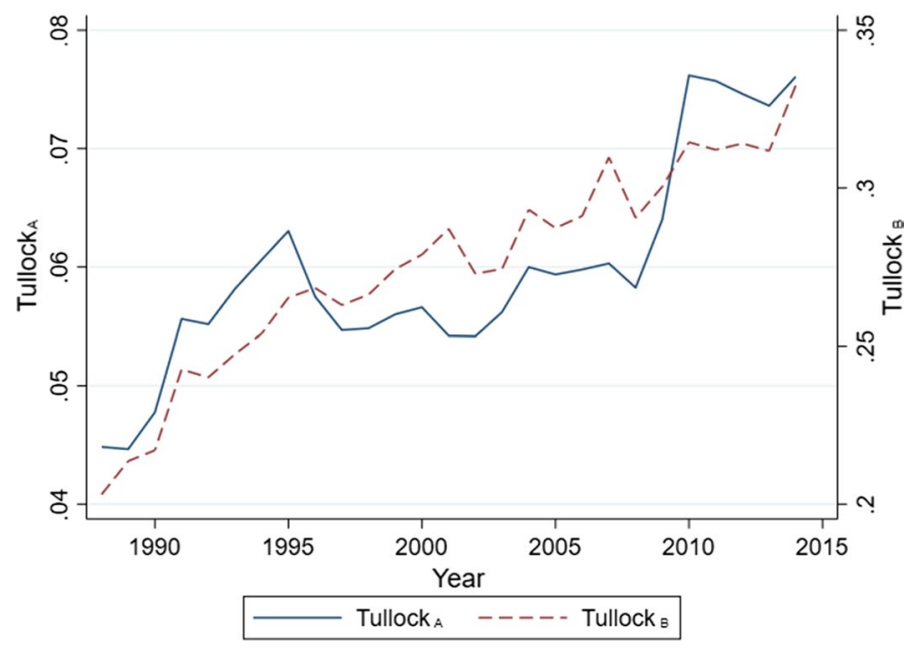

Fig. 4 Tullock indices over time

Figure 4 plots trends in both versions of the Tullock index over the sample period. ${ }^{7}$ The figure suggests that the transfer system has become less effective over time. ${ }^{8}$ From 1988 to 2014, Tullock $_{A}$ increases from approximately 0.045 to 0.07 , indicating that current transfer spending could achieve a 7\% larger reduction in inequality, were it better targeted. Perhaps what is more important, the value of Tullock $_{B}$ approaches 0.35 by the end of the sample period, indicating that the current level of post-transfer inequality could be achieved with nearly $35 \%$ less transfer spending.

The results in Fig. 4 suggest that Tullock's concerns about the ineffectiveness of equilibrium redistribution are warranted. From the perspective of someone who accepts the egalitarian assumption, a significant fraction of current transfers appear to be ineffective. That conclusion is true even if one believes that the government has an obligation to adopt transfer programs to reduce inequality. As such, important policy questions arise concerning the institutional environment that gives rise to ineffective transfers, as well as the consequences of ineffective transfers for outcomes related to household welfare, including poverty and employment. To examine those questions in further detail, I turn to the construction of the Tullock index at the state-level.

\footnotetext{
${ }^{7}$ Additional summary statistics for the full IPUMS CPS sample are presented in Appendix 2.

${ }^{8}$ To verify that the upward trend is not an artifact of the IPUMS data, I construct an estimate of Tullock $_{A}$ relying on average market and transfer incomes by quintile from the Congressional Budget Office's (CBO) Distribution of Household Income Report. The results, presented in Appendix 3, verify the upward trend indicated in Fig. 4.
} 


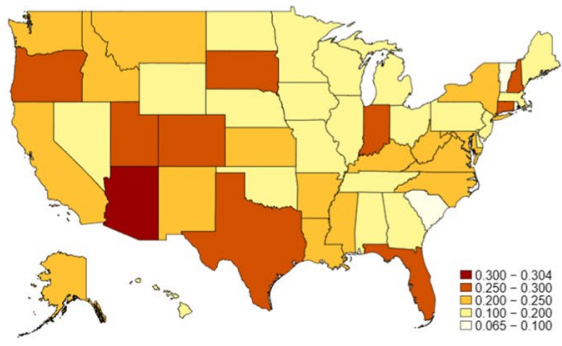

(a) Tullock $_{A} 1988$

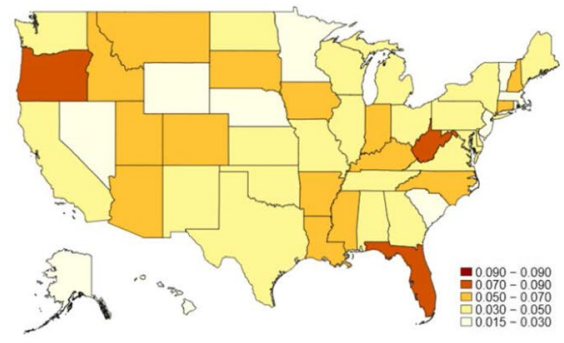

(c) Tullock $_{B} 1988$

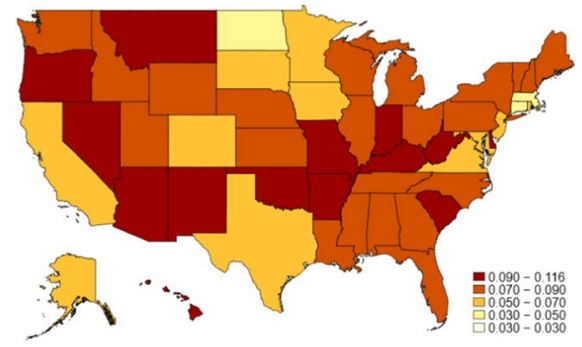

(b) Tullock $_{A} 2014$

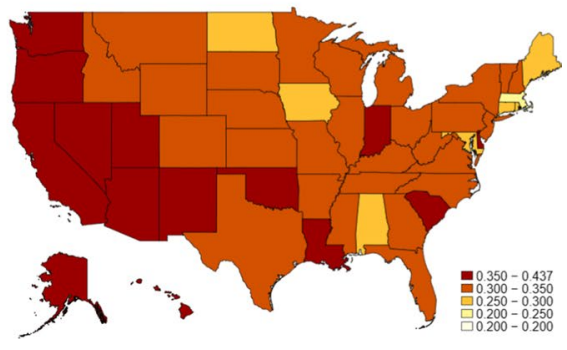

(d) Tullock $_{B} 2014$

Fig. 5 Mapping the Tullock index

\section{State-level results}

To construct estimates of the Tullock index at the state-level, I follow the procedures outlined in Sect. 3 separately for each year for each US state using the IPUMS CPS data. Figure 5 maps Tullock $_{A}$ and Tullock $_{B}$ across states for the years 1988 and 2014. ${ }^{9}$ Figure 5 indicates the same pattern of reduced effectiveness as does Fig. 4, but is not suggestive of any particular geographic pattern. The increase in the Tullock index appears to hold geographically, impacting states in all regions of the country.

To examine the effects of the Tullock Index on state-level economic activity, as well as the institutional factors that may be correlated with increases in it, I obtain data from several additional sources. Observations on state-level GDP are obtained from the Bureau of Economic Analysis (BEA) Regional Economic Accounts. State-level employment is obtained from the Bureau of Labor Statistics (BLS). Table 1 presents sample means for key variables in the state-level analysis.

"Poverty rate (\%)" measures the percentage of individuals below the official poverty line, as measured using the Census Bureau poverty thresholds reported in the IPUMS CPS data. "Employment-population rate (\%)" is the employment to population ratio reported by the BLS. "Ln(Per-capita GDP)" is the natural log of state-level real per-capita gross domestic product from the BEA Regional Economic Accounts. "Ln(Per-capita transfer income)" is the natural log of state-level real per-capita transfer income, as calculated from the IPUMS CPS data. "College(\%)" measures the share of a state's population holding a

\footnotetext{
9 Table 6 in Appendix 4 reports the average value of each version of the Tullock index for each state over the sample period.
} 
Table 1 State-level sample means

\begin{tabular}{ll}
\hline & Mean \\
& $(\mathrm{SD})$ \\
\hline Tullock $_{A}$ & 0.0617 \\
& $(0.0198)$ \\
Tullock $_{B}$ & 0.271 \\
& $(0.0636)$ \\
Poverty rate (\%) & 12.69 \\
& $(3.390)$ \\
Employment-population rate (\%) & 63.05 \\
& $(4.507)$ \\
Ln(Employment) & 14.07 \\
& $(1.025)$ \\
Employment growth (\%) & 1.211 \\
& $(2.294)$ \\
Ln(Per-capita GDP) & 10.24 \\
& $(0.253)$ \\
Ln(Per-capita transfer income) & 8.159 \\
& $(0.132)$ \\
College (\%) & 25.95 \\
& $(6.448)$ \\
White (\%) & 78.27 \\
Black (\%) & $(14.81)$ \\
& 10.32 \\
Hispanic (\%) & $(10.95)$ \\
& 6.510 \\
& $(7.316)$ \\
& 1.177 \\
& $(2.118)$ \\
& 2.280 \\
& $(6.454)$ \\
& 1,377 \\
\hline
\end{tabular}

Table presents state-level sample means. Standard deviations in parenthesis

college degree. The race variables "White(\%)", "Black(\%)", and so on measure the share of a state's population of a specific race.

Figure 6 displays binned scatterplots of several variables of interest against both versions of the Tullock index (after residualizing on state-fixed effects). The results are suggestive: independent of any additional controls, both versions of the Tullock index are positively correlated with poverty rates and negatively correlated with the employment-topopulation ratio. To investigate the impact of redistributional ineffectiveness on state-level outcomes in further detail, I estimate the following panel fixed-effects model:

$$
Y_{i t}=\beta_{0}+\beta_{1} \text { Tullock }_{i t}+X_{i t}^{T} \beta+\delta_{t}+\gamma_{i}+\epsilon_{i t}
$$




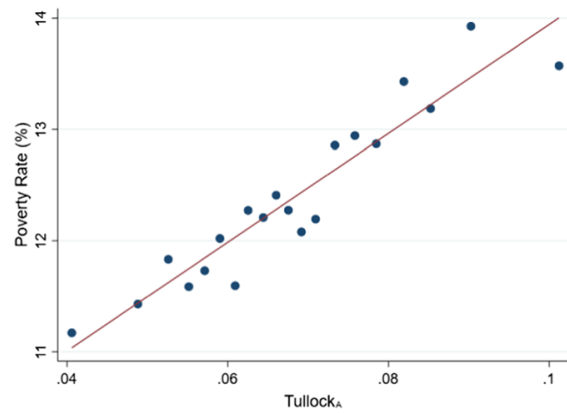

(a) Tullock $_{A}$ versus poverty

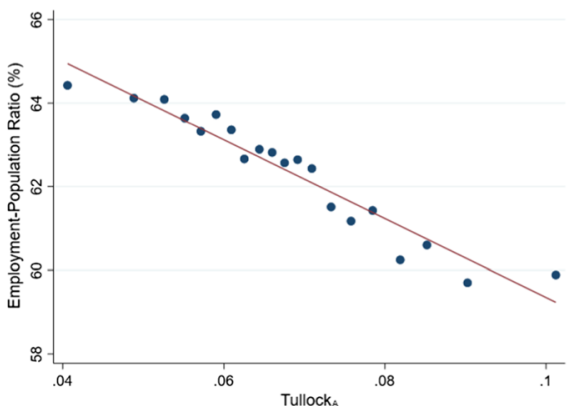

(c) Tullock $_{A}$ versus $\frac{E m p}{\text { Pop }}$

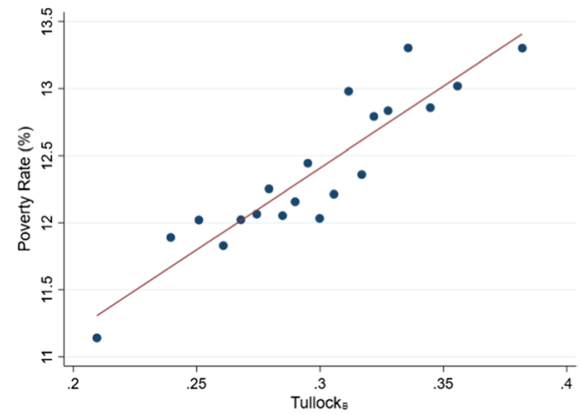

(b) Tullock $k_{B}$ versus poverty

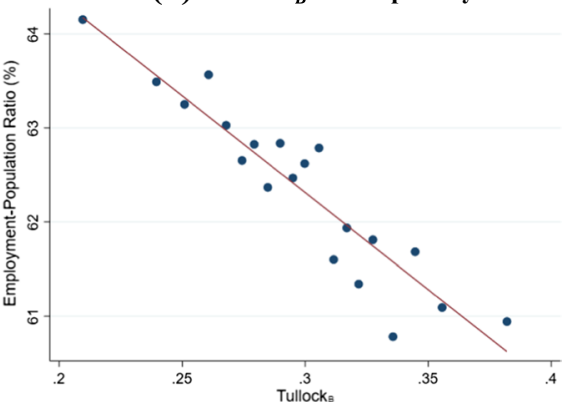

(d) Tullock $_{B}$ versus $\frac{E m p}{\text { Pop }}$

Fig. 6 Tullock index scatterplots. Notes Figure presents binned scatterplots of each independent variable against both versions of the Tullock Index

where $Y_{i t}$ is the state-level outcome of interest-either poverty, the level of employment, or the employment-population ratio, Tullock ${ }_{i t}$ is the Tullock index, $\boldsymbol{X}_{i t}$ is a vector of statelevel controls, $\delta_{t}$ is a year-fixed effect, $\gamma_{i}$ is a state-fixed effect, and $\epsilon_{i t}$ is an idiosyncratic error term. The results from estimating Eq. 3 should be interpreted with caution. Although state-fixed effects will address any time-invariant state-specific unobserved heterogeneity and year-fixed effects will capture any timewise-common shocks faced by all states, unobserved state-level factors nevertheless may influence the relationship between the Tullock index and economic activity that preclude a causal interpretation of the results. In this sense, estimates of $\beta_{1}$ obtained from Eq. 3 are pure correlations. However, with that caveat in mind, it is worth emphasizing that the correlations observed will nonetheless be informative, given what theory says about the expected relationship between ineffective redistribution and economic activity (i.e., the impact of ineffective redistribution on economic activity should be negative).

The results from estimating Eq. 3 with poverty as the dependent variable are presented in Table 2. In each case, the Tullock index is scaled by 100 to aid with interpretation. The results suggest that ineffective transfers have a significant effect on poverty. In particular, the results show that a unit increase in Tullock $_{A}$ raises the poverty rate by close to one-third of a percentage point, while a unit increase in Tullock $_{B}$ raises the poverty rate by about three one-hundredths of a percentage point. Alternatively, a onestandard deviation increase in Tullock $_{A}$ (an increase of 1.98) would elevate the poverty rate by about one-half a percentage point, while a one-standard deviation increase in 
Table 2 Estimation results: poverty

(1)

(2)

(3)

(4)

(5)

(6)

Poverty:Tullock

\begin{tabular}{|c|c|c|c|c|c|c|}
\hline Tullock $_{A}$ & $\begin{array}{l}0.315^{* * *} \\
(0.0837)\end{array}$ & $\begin{array}{l}0.218 * * \\
(0.0838)\end{array}$ & $\begin{array}{l}0.110 * * * \\
(0.0334)\end{array}$ & $\begin{array}{l}0.327 * * * \\
(0.0754)\end{array}$ & $\begin{array}{l}0.260 * * * \\
(0.0781)\end{array}$ & $\begin{array}{l}0.224 * * * \\
(0.0422)\end{array}$ \\
\hline Ln(Per-capita transfer income) & & & & $\begin{array}{l}-0.361 \\
(1.325)\end{array}$ & $\begin{array}{l}-1.194 \\
(1.714)\end{array}$ & $\begin{array}{l}-3.602 * * * \\
(0.926)\end{array}$ \\
\hline$N$ & 1,377 & 1,377 & 1,377 & 1,377 & 1,377 & 1,377 \\
\hline Controls & $\mathrm{Y}$ & $\mathrm{Y}$ & $\mathrm{Y}$ & $\mathrm{Y}$ & $\mathrm{Y}$ & $\mathrm{Y}$ \\
\hline Year FE & $\mathrm{N}$ & $\mathrm{Y}$ & $\mathrm{Y}$ & $\mathrm{N}$ & $\mathrm{Y}$ & $\mathrm{Y}$ \\
\hline State FE & $\mathrm{N}$ & $\mathrm{N}$ & $\mathrm{Y}$ & $\mathrm{N}$ & $\mathrm{N}$ & $\mathrm{Y}$ \\
\hline Poverty:Tullock ${ }_{B}$ & & & & & & \\
\hline Tullock $_{B}$ & $\begin{array}{l}0.0292 \\
(0.0211)\end{array}$ & $\begin{array}{l}0.0277 \\
(0.0208)\end{array}$ & $\begin{array}{l}0.0333 * * * \\
(0.00959)\end{array}$ & $\begin{array}{l}0.00635 \\
(0.0197)\end{array}$ & $\begin{array}{l}0.0192 \\
(0.0205)\end{array}$ & $\begin{array}{l}0.0511 \text { *** } \\
(0.0111)\end{array}$ \\
\hline Ln(Per-capita transfer income) & & & & $\begin{array}{l}3.250 * * \\
(1.544)\end{array}$ & $\begin{array}{l}1.187 \\
(1.824)\end{array}$ & $\begin{array}{l}-2.603 * * * * \\
(0.797)\end{array}$ \\
\hline$N$ & 1,377 & 1,377 & 1,377 & 1,377 & 1,377 & 1,377 \\
\hline Controls & $\mathrm{Y}$ & $\mathrm{Y}$ & $\mathrm{Y}$ & $\mathrm{Y}$ & $\mathrm{Y}$ & $\mathrm{Y}$ \\
\hline Year FE & $\mathrm{N}$ & $\mathrm{Y}$ & Y & $\mathrm{N}$ & $\mathrm{Y}$ & Y \\
\hline State FE & $\mathrm{N}$ & $\mathrm{N}$ & $\mathrm{Y}$ & $\mathrm{N}$ & $\mathrm{N}$ & $\mathrm{Y}$ \\
\hline
\end{tabular}

Standard errors in parentheses, clustered at the state level. ${ }^{*} p<0.10,{ }^{* *} p<0.05,{ }^{* * *} p<0.01$. In each regression, the Tullock index is scaled by 100 , such that a unit increase in Tullock $k_{A}$ corresponds to a $1 \%$ increase in "wasted" inequality, and a unit increase in Tullock ${ }_{B}$ corresponds to a $1 \%$ increase in "wasted" transfers. Control variables include $(\log )$ per-capita GDP, $(\log )$ employment, $(\log )$ state population, the percentage of individuals in a state with at least a bachelor's degree, and population shares for age, race, and gender groups

Tullock $_{B}$ (an increase of 6.36) is associated with a one-fifth of a percentage point rise in the poverty rate. To understand the significance of that finding, note that the estimates in Column (6) suggest that-after controlling for state-fixed effects-transfers have a negative and significant impact on poverty, all else equal.

Even so, ineffective redistribution substantially mitigates the poverty-reduction effect of transfers. At the mean level of Tullock ${ }_{A}$, the poverty rate is 1.4 percentage points higher than it otherwise would be-given the current level of transfers-were there no ineffective transfers. A similar effect is implied by the regression coefficient on Tullock . $_{\text {. }}$ That the impact of the Tullock index remains negative after entering per-capita transfers as a control also is suggestive. The result indicates that the index is not merely picking up the presence of larger transfers, but rather that redistributional ineffectiveness exerts a negative impact on economic activity, holding the level of transfers constant.

Table 3 presents results from estimating Eq. 3 using either the employment-population ratio or the natural $\log$ of employment as the dependent variable. The empirical results again suggest that ineffective transfers reduce economic activity. Both the employment-population ratio and the level of employment are declining in Tullock $_{A}$ and Tullock $_{B}$. Furthermore, in the case of the employment-population ratio, the per-capita amount of transfers has a negative effect, consistent with an undesirable incentive effect. 


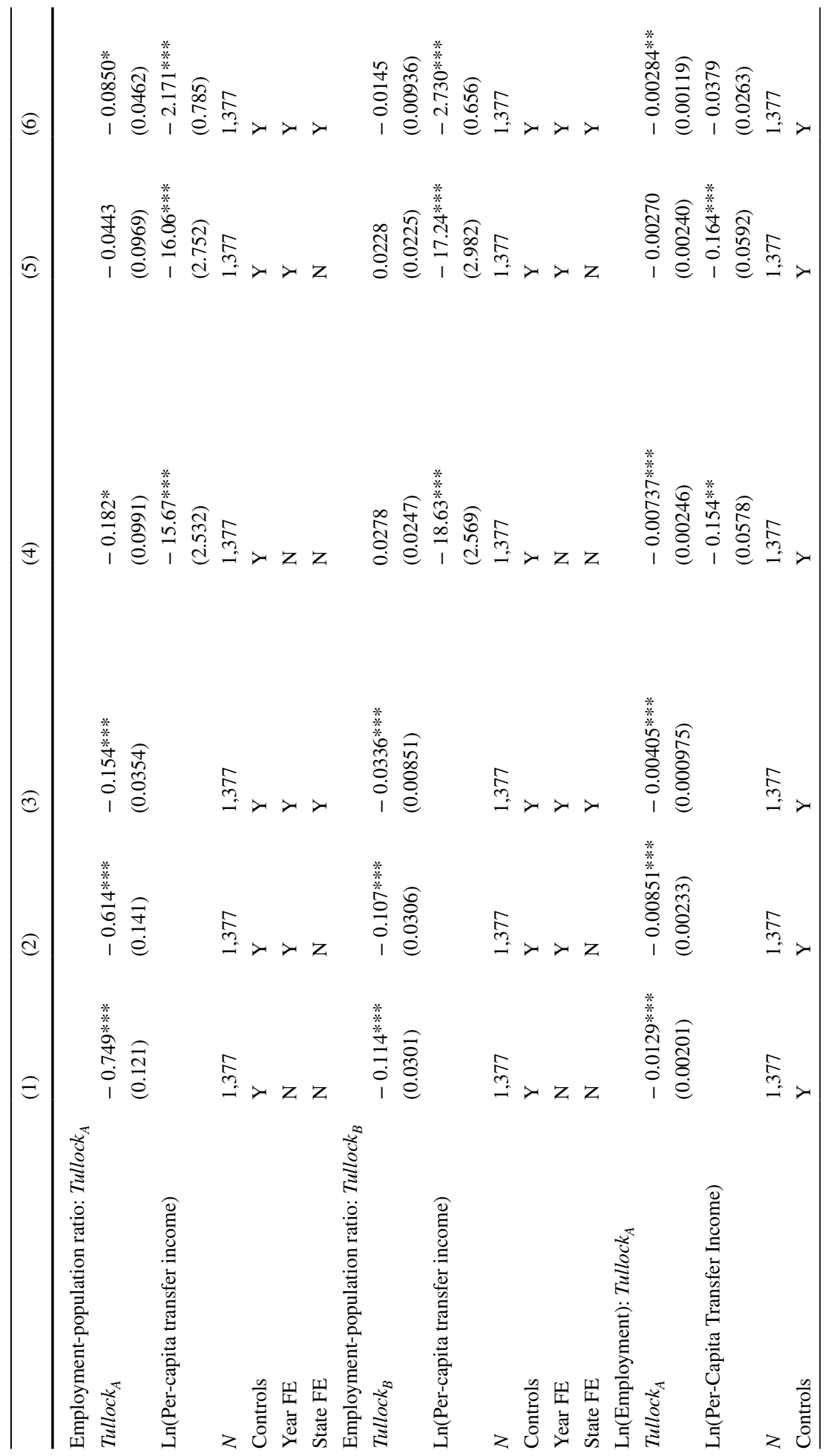




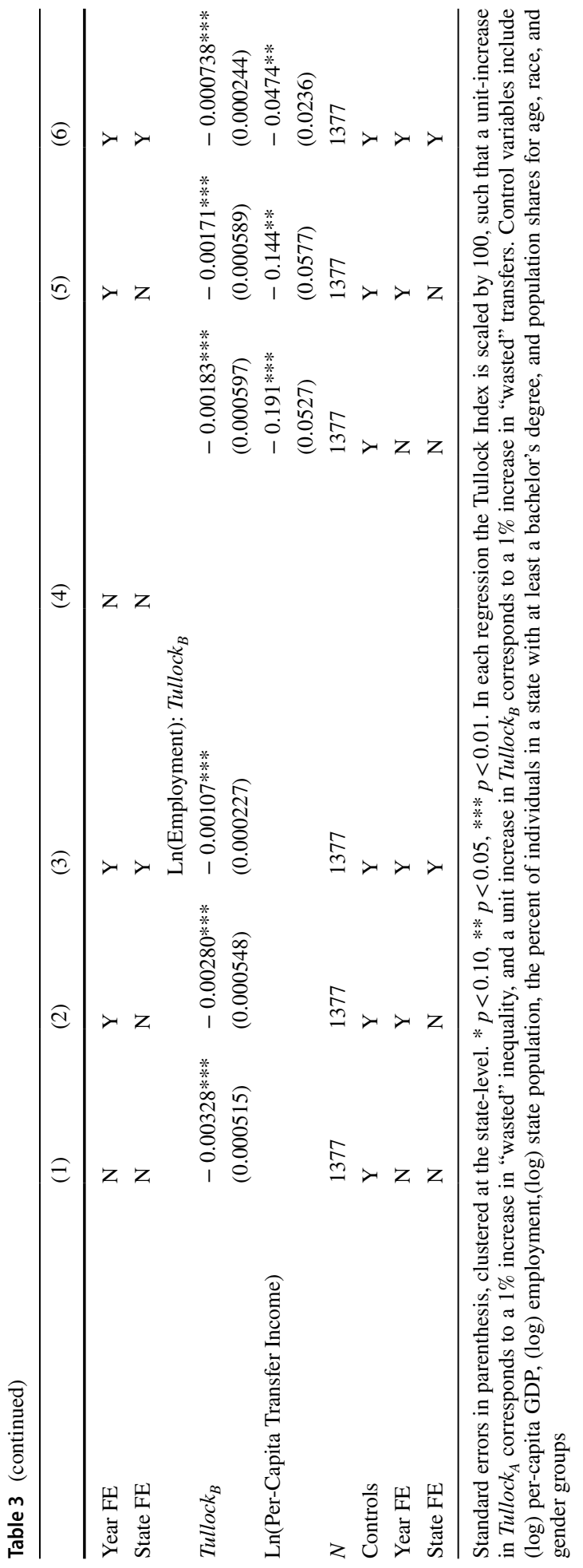


Despite the negative estimated effect, the employment impact of ineffective transfers seems to be smaller than that of ineffective transfers on poverty, particularly for the employment-population ratio. The drop in the estimated size of the regression coefficients between Columns (1)-(3) and Columns (4)-(6) hints that the observed dis-employment effect may be driven by the transfer programs themselves, rather than ineffectiveness in the transfer system. In Column (6), the coefficient on Tullock $_{A}$ implies that redistributional ineffectiveness is responsible for a reduction in the employment-population ratio of about 0.5 percentage points at the mean (while the coefficient on Tullock $_{B}$ is statistically insignificant). The effects on the level of employment are somewhat larger, with Column (6) suggesting a unit increase in Tullock $_{A}$ reduces the level of employment by approximately $0.28 \%$ (the size of the for Tullock $k_{B}$ is roughly similar). In contrast, the naive point estimates indicate that transfers reduce the employment-population ratio up to 14 percentage points at the mean, a comparatively large effect. ${ }^{10}$

\section{Conclusion}

This paper provides an empirical framework for evaluating Tullock's (1971, p. 269) claim that the majority of income redistribution in the United States represents "transfers from groups of people who, for one reason or another, are not politically powerful to people who are.” In particular, I rely on Current Population Survey microdata from 1988 to 2014 to construct two versions of a "Tullock index" for assessing the effectiveness of redistribution. Each version of the index adopts the egalitarian assumption: that the goal of redistribution is to achieve the largest possible reduction in inequality at the least cost. Version $\mathbf{A}$ of the Tullock index measures deviations from the egalitarian assumption by calculating the maximum possible inequality reduction attainable with current levels of transfer spending under a lump-sum transfer policy. Version $\mathbf{B}$ of the Tullock index measures deviations from the egalitarian assumption by calculating the minimum per-capita lump-sum transfer necessary to achieve the current level of post-transfer inequality. Both versions of the index suggest that redistribution has become less effective over the sample period. In particular, Version B of the Tullock Index suggests that by 2014, approximately $30 \%$ of transfers are "wasted" with respect to the attainment of the current level of post-transfer inequality. State-level panel fixed-effects estimates show that redistributional ineffectivenessas measured by the Tullock index-is related to higher state-level poverty rates, lower employment-to-population ratios, and lower levels of overall employment. These findings have important implications for contemporary efforts at income redistribution, including policies adopted as part of the US government response to the Covid-19 pandemic. To take one example, the findings in this paper suggest that-given the observed decline in the effectiveness of redistribution over time-it should come as no surprise that Paycheck Protection Program (PPP) loans appear to have been largely targeted at high income communities (Schweitzer \& Borawski, 2021).

Two important questions remain. First, how should academics and policymakers respond to ineffective transfer programs? A common approach of fiscally conscious policymakers is to advocate for more means-testing in government transfer programs. While

\footnotetext{
${ }_{10}$ Part of the effect may be a mechanical correlation, as per-capita transfer spending includes spending on unemployment insurance.
} 
the present paper is agnostic about the overall impact of such efforts, it is worth noting that a large empirical literature finds the introduction of means testing to be associated with various perverse disincentives (from work disincentives to savings disincentives) owing to high marginal tax rates in the program phase-out region (Autor \& Duggan, 2007; Fetter \& Lockwood, 2018; Gray et al., 2021; Powers, 1998). Furthermore, the results in Table 2 suggest that - despite the presence of ineffective transfers-transfers do have a negative and significant effect on poverty. Thus, in the absence of a specific policy recommendation, policymakers should exercise caution to ensure that the "cure" for ineffective redistributionist policy is not worse than the disease.

Second, to what extent is it reasonable to assume an egalitarian objective when constructing an index to measure the effectiveness of redistribution? That is, might other goals or objectives-when assumed-would rationalize the observed pattern of redistribution? Although Sect. 2.1 discusses several possible justifications for redistribution, in each case the resulting transfers would either (A) be likely to satisfy the egalitarian assumption (e.g., as in the cases of other regarding preferences over income or redistribution as income insurance), or (B) are unlikely to apply to the data examined here (it is difficult to appeal to externalities in production as an explanation for the sorts transfers received by households in the CPS). Thus, even if one accepts the justifications for redistribution given in Sect. 2.1, they offer no explanation for how the deviations from the egalitarian assumption measured by the Tullock index might otherwise be considered to represent "effective" redistribution.

One possibility is that income transfers violating the egalitarian assumption satisfy some alternative preference for transfers-in-kind. As Buchanan (1968) points out, it may be the case that an individual cares not about her neighbor's income in general, but about her neighbor's consumption level of specific goods (e.g., education, healthcare) or her neighbor's income at specific points in time (e.g., old age). In that case, transfers that violate the egalitarian assumption (by moving money back and forth between the middle class through programs like social security or education subsidies) may nonetheless represent an effective use of the transfer system. If such preferences are assumed, the Tullock index will overstate the extent to which the transfer system is ineffective at achieving its objective.

Nonetheless, it is likely that certain elements of the tax and transfer system satisfy neither the egalitarian assumption nor broader criteria encompassing transfers in-kind. First, it is possible that - following Brennan and Buchanan's (1980) characterization of government as Leviathan - a large tax-and-transfer system may function as a means of maintaining government power through patronage jobs. Alternatively, if Tullock is correct, the median voter may simply desire transfers for herself, regardless of the impact of transfers on inequality. Farm subsidies, import tariffs, and auto company bailouts are all examples of transfers that essentially have nothing to do with alleviating inequality. Many of the most common income tax deductions also serve as examples of transfers that clearly are not intended to reduce inequality. Williams (2021) shows that nine of the largest tax deductions in the United States ${ }^{11}$ transfer close to $\$ 650$ billion a year up the income distribution. Furthermore, Williams (2021) shows that these transfers contribute substantially to racial wealth inequality: of the nearly $\$ 400$ billion in annual federal spending on deductions for tax-exempt bonds, realized capital gains, pension wealth, and inherited wealth, close to $100 \%$ goes to white households. It is hard to see how such transfers satisfy either

\footnotetext{
11 The deductions include home mortgage interest, charitable contributions, state and local taxes paid, rollovers of capital gains on home sales, tax-exempt bonds, life insurance payouts, pensions, capital gains exclusion, and estate step-ups.
} 
Table 4 Income concepts: component parts

Market income
Wage and salary income Total pre-tax wage and
salary income-that is, money received as an
employee-for the previous calendar year
Business income Net pre-income-tax non- farm
business and/or professional practice in- come for
the previous calendar year

Farm income Net pre-income-tax earnings as a tenant farmer, sharecropper, or operator of his or her own farm during the previous calendar year

Retirement income Pre-tax income received from all retirement income sources during the past year. Pension or retirement income from a previous employer or union, or from other retirement income (excluding Social Security and Veterans' Administration payments) are in- cluded

Dividend income Pre-tax income received from stocks and mutual funds during the pre- vious calendar year

Interest income Pre-tax income received from interest on saving accounts, certificates of deposit, money market funds, bonds, treasury notes, IRAs, and/or other investments which paid interest

Rental income Pre-tax income received from rent (after expenses), from charges to roomers or boarders, and from money paid by estates, trusts, and royalties, during the previous calen- dar year

Other market income A residual category for pre-tax income for the previous calendar year that was not reported in other, more spe- cific, income variables. Small amounts of in- come from hobbies, severance pay, and foster child care payments are included
Transfer income

Social security income Pre-tax income the respondent received from Social Security

Welfare income Pre-tax income the respon- dent received during the previous calendar year from various public assistance programs com- monly referred to as "welfare."

Supplemental security income Pre-tax in- come received from Supplemental Security In- come (SSI) during the previous calendar year

Unemployment income Pre-tax income re- ceived from state or federal unemployment compensation, Supplemental Unemployment Benefits (SUB), or union unemployment or strike benefits during the previous calendar year

Worker's comp Pre-tax income received from worker's compensation payments or other payments as a result as a job-related injury or illness

Veteran's income and survivors' benefits Pre-tax income received from payments from the Veterans' Administration (VA) or survivors' benefits during the previous calendar year

Disability income Pre-tax income received from disability income during the previous cal- endar year

Educational income Pre-tax income received from educational assistance during the previous calendar year. This variable relates to educa- tion beyond the high school level, including col- lege, university, or vocational, business, or trade school

Other non-market income Pre-tax income received from other non-market sources, in- cluding child support payments, alimony pay- ments, and familial assistance

the egalitarian assumption or even very strong preferences for transfers-in-kind. Thus, even if the transfers measured in the CPS data examined in this paper are "effective" under the assumption of a preference for transfers-in-kind; many transfers will remain ineffective to the extent that they take the form of tax credits and deductions that are far less likely to be justifiable. The questionable nature of many such tax credits and deductions therefore points to the importance of extending the Tullock index to the tax side of the government budget in future work.

Finally, to the extent that either the Leviathan perspective of Brennan and Buchanan (1980) or the equilibrium redistribution theory of Tullock (1981) is correct, reducing inequality may not be the primary goal of the transfer system. If so, the rising Tullock index over time documented herein simply indicates that that government is functioning "as intended". That seems to be the natural conclusion for those inclined to the "politics 
Table 5 Sample means-full IPUMS CPS sample

\begin{tabular}{ll}
\hline & $\begin{array}{l}\text { Mean } \\
(\mathrm{SD})\end{array}$ \\
\hline Gini coefficient, market income & 0.564 \\
& $(0.0347)$ \\
Gini coefficient, post-transfer income & 0.481 \\
& $(0.0330)$ \\
Gini coefficient, counterfactual income & 0.452 \\
& $(0.0285)$ \\
Total post-transfer income & $32,405.3$ \\
& $(1085.1)$ \\
Market income & $28,868.3$ \\
& $(1237.2)$ \\
Transfer income & $3,537.0$ \\
& $(207.4)$ \\
Counterfactual income & $32,405.3$ \\
Actual transfers per-capita & $(1085.1)$ \\
& $3,537.0$ \\
Counterfactual transfers per-capita & $(207.4)$ \\
& $2,559.6$ \\
Tullock & $(103.2)$ \\
Tullock & \\
$N$ & 0.0597 \\
& $(0.00883)$ \\
& 0.275 \\
& $(0.0330)$ \\
& $1,777,345$ \\
\hline
\end{tabular}

Standard deviations in parentheses. Sample means calculated using IPUMS CPS sample weights. Dollar amounts are reported in constant 1999 dollars. "Counterfactual Income" refers to the income counterfactual computed in the construction of Tullock ${ }_{A}$. "Actual Transfers Per-Capita" measures the total value of transfers divided by the total number of individuals in the sample. "Counterfactual Transfers PerCapita" measures the total value of counterfactual transfers computed in the construction of Tullock $_{B}$, divided by the total number of individuals in the sample

without romance" approach for which public choice scholarship is famous. Whether that conclusion implies that the tax-and-transfer system - as constituted - therefore is desirable, is another question entirely.

\section{Appendices}

\section{Appendix 1: Income concepts}

Table 4 provides detailed descriptions of the component parts of the market income and transfer income concepts used in the body of the paper. Total personal income is calculated as the sum of market income and transfer income. 


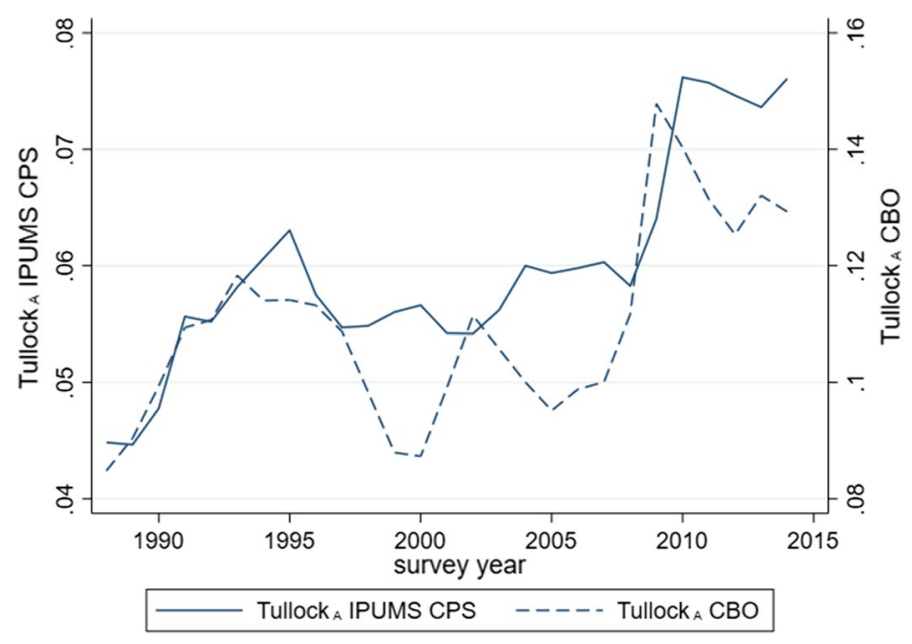

Fig. 7 CBO data versus IPUMS data

\section{Appendix 2: Additional Summary Statistics}

Table 5 presents sample means for key variables from the full IPUMS CPS sample. "Counterfactual income" refers to the income counterfactual computed in the con-

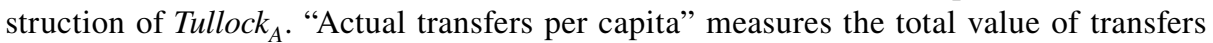
divided by the total number of individuals in the sample. "Counterfactual transfers per capita" measures the total value of counterfactual transfers computed in the construction of Tullock ${ }_{B}$, divided by the total number of individuals in the sample. A small number of individuals reporting negative values for total personal income, market income, or transfer income are excluded from the analysis.

\section{Appendix 3: Comparison with Congressional Budget Office data}

Relying on tax data, the Congressional Budget Office (CBO) produces regular reports on the distribution of income in the United States and how the distribution has changed over time. The most recent iteration presents the distributions of household income, means-tested transfers, and federal taxes between 1979 and 2017. These data contain information on average income before transfers and average transfers received by income quintile, allowing Tullock $_{A}$ to be constructed following the process outlined in Sect. 3. Figure 7 plots the series for Tullock $_{A}$ generated from the CBO data against the series generated from the IPUMS CPS data. Although differences in levels arise (in particular, the $\mathrm{CBO}$ data result in somewhat inflated estimates of the Tullock index), both series display the same upward trend in redistributional ineffectiveness, suggesting that the trend is not simply an artifact of the IPUMS data. 
Table 6 State-by-state Tullock index means, 1988-2014

\begin{tabular}{|c|c|c|}
\hline State & Tullock $_{A}$ & Tullock $_{B}$ \\
\hline Alabama & 0.068 & 0.269 \\
\hline Alaska & 0.045 & 0.295 \\
\hline Arizona & 0.074 & 0.341 \\
\hline Arkansas & 0.079 & 0.270 \\
\hline California & 0.060 & 0.311 \\
\hline Colorado & 0.050 & 0.286 \\
\hline Connecticut & 0.055 & 0.274 \\
\hline Delaware & 0.065 & 0.283 \\
\hline District of Columbia & 0.046 & 0.291 \\
\hline Florida & 0.083 & 0.326 \\
\hline Georgia & 0.048 & 0.244 \\
\hline Hawaii & 0.065 & 0.297 \\
\hline Idaho & 0.061 & 0.263 \\
\hline Illinois & 0.048 & 0.239 \\
\hline Indiana & 0.058 & 0.239 \\
\hline Iowa & 0.057 & 0.237 \\
\hline Kansas & 0.057 & 0.249 \\
\hline Kentucky & 0.075 & 0.276 \\
\hline Louisiana & 0.060 & 0.257 \\
\hline Maine & 0.065 & 0.239 \\
\hline Maryland & 0.045 & 0.259 \\
\hline Massachusetts & 0.052 & 0.245 \\
\hline Michigan & 0.057 & 0.237 \\
\hline Minnesota & 0.047 & 0.227 \\
\hline Mississippi & 0.074 & 0.278 \\
\hline Missouri & 0.063 & 0.258 \\
\hline Montana & 0.084 & 0.293 \\
\hline Nebraska & 0.060 & 0.268 \\
\hline Nevada & 0.058 & 0.274 \\
\hline New Hampshire & 0.048 & 0.235 \\
\hline New Jersey & 0.048 & 0.252 \\
\hline New Mexico & 0.082 & 0.346 \\
\hline New York & 0.066 & 0.303 \\
\hline North Carolina & 0.063 & 0.267 \\
\hline North Dakota & 0.053 & 0.231 \\
\hline Ohio & 0.058 & 0.239 \\
\hline Oklahoma & 0.073 & 0.290 \\
\hline Oregon & 0.072 & 0.292 \\
\hline Pennsylvania & 0.061 & 0.242 \\
\hline Rhode Island & 0.065 & 0.258 \\
\hline South Carolina & 0.069 & 0.270 \\
\hline South Dakota & 0.068 & 0.278 \\
\hline Tennessee & 0.066 & 0.272 \\
\hline Texas & 0.056 & 0.304 \\
\hline Utah & 0.049 & 0.256 \\
\hline Vermont & 0.066 & 0.265 \\
\hline
\end{tabular}


Table 6 (continued)

\begin{tabular}{lll}
\hline State & Tullock $_{A}$ & Tullock $_{B}$ \\
\hline Virginia & 0.054 & 0.301 \\
Washington & 0.061 & 0.285 \\
West Virginia & 0.097 & 0.289 \\
Wisconsin & 0.058 & 0.245 \\
Wyoming & 0.055 & 0.253 \\
\hline
\end{tabular}

\section{Appendix 4: State-by-state Tullock index means}

Table 6 presents state-by-state means for both versions of the Tullock index over the entire sample period.

Acknowledgements I would like to thank Randall Holcombe, Nikolai Wenzel, two anonymous referees, and participants at the 2021 Southern Economic Association Annual Meetings for helpful comments and criticism. All remaining errors are my own.

\section{References}

Autor, D., \& Duggan, M. (2007). Distinguishing income from substitution effects in disability insurance. American Economic Review, 97(2), 119-124.

Atkinson, T. (1970). On the measurement of inequality. Journal of Economic Theory, 2, 244-263.

Brennan, G., \& Buchanan, J. M. (1980). The power to tax: Analytical foundations of a fiscal constitution. Cambridge University Press.

Buchanan, J. (1968). What kind of redistribution do we want? Economica, 35(138), 185-190.

Buchanan, J. (1976). A Hobbesian interpretation of the Rawlsian difference principle. Kyklos, 29, 5-25.

Buchanan, J. (1985). Political economy and social philosophy. In The Collected Works of James M. Buchanan, Vol. 17, p. 235-250. Liberty Fund.

Buchanan, J., \& Tullock, G. (1962). The calculus of consent: Logical Foundations of Constitutional Democracy. University of Michigan Press.

Fetter, D., \& Lockwood, L. (2018). Government old-age support and labor supply: Evidence from the OldAge Assistance Program. American Economic Review, 108(8), 2174-2211.

Flood, S., King, M., Rodgers, R., Ruggles, S., \& Warren, R. (2020). Integrated public use microdata series, current population survey: Version 8.0. IPUMS. https://doi.org/10.18128/D030.V8.0

Friedman, M. (1947). Lerner on the economics of control. Journal of Political Economy, 55(5), 405-416.

Friedman, M. (1962). Capitalism and Freedom. University of Chicago Press.

Gray, C., Leive, A., Prager, E., Pukelis, K., \& Zaki, M. (2021). Employed in a SNAP? The impact of work requirements on program participation and labor supply. NBER Working Paper, No. 28877.

Hendrickson, J., Salter, A., \& Albrecht, B. (2018). Preventing plunder: Military technology, capital accumulation, and economic growth. Journal of Macroeconomics, 58, 154-173.

Hochman, H., \& Rogers, J. (1969). Pareto optimal redistribution. American Economic Re-View, 59(4), $542-557$.

Lerner, A. (1944). The economics of control. Macmillan.

Marglin, S. (1963). The social rate of discount and the optimal rate of investment. Quarterly Journal of Economics, 77(1), 95-111.

Petach, L., \& Tavani, D. (2019). No one is alone: Strategic complementarities, capacity utilization, growth, and distribution. Structural Change and Economic Dynamics, 50, 203-215.

Petach, L., \& Tavani, D. (2022). Aggregate demand externalities, income distribution, and wealth inequality. Structural Change and Economic Dynamics, 60, 433-446.

Powers, E. (1998). Does means-testing welfare discourage saving? Evidence from a change in AFDC policy in the United States. Journal of Public Economics, 68(1), 33-53.

Rawls, J. (1971). A theory of justice. Harvard University Press.

Robbins, J. (1938). Interpersonal comparisons of utility: A comment. Economic Journal, 48(192), 635-641. 
Samuelson, P. (1954). The pure theory of public expenditure. Review of Economics and Statistics, 36(4), 387-389.

Schweitzer, M., \& Borawski, G. (2021). How well did PPP loans reach low- and moderate income communities? Federal Reserve Bank of Cleveland Economic Commentary. https://doi.org/10.26509/ frbc-ec-202113.

Tavani, D., \& Petach, L. (2021). Firm beliefs and long-run demand effects in a labor-constrained model of growth and distribution. Journal of Evolutionary Economics, 31, 353-377.

Thompson, E. (1974). Taxation and national defense. Journal of Political Economy, 82(4), 755-782.

Tullock, G. (1959). Problems of majority voting. Journal of Political Economy, 67, 571-579.

Tullock, G. (1971). The charity of the uncharitable. Western Economic Journal, 9, 379-392. Reprinted in Rowley, C., (Ed). Virginia Political Economy (pp. 262-275). Liberty Fund.

Tullock, G. (1981). The rhetoric and reality of redistribution. Southern Economic Journal, 47, 895-907.

Tullock, G. (1983a). Helping the poor vs. helping the well-organized. In Rowley, C. (Ed). The Economics and Politics of Wealth Redistribution (pp.171-178). Liberty Fund.

Tullock, G. (1983b). Reasons for redistribution [1983b]. In Rowley, C. (Ed). The economics and politics of wealth redistribution (pp.23-41). Liberty Fund.

Tullock, G. (1986). Reasons for redistribution [1986]. In Rowley, C. (Ed). The economics and politics of wealth redistribution (pp. 42-70). Liberty Fund.

Wessels, J. (1993). Redistribution from a constitutional perspective. Constitutional Political Economy, 4(3), $425-448$.

Williams, R. (2021). Federal wealth policy and the perpetuation of white supremacy. Review of Black Political Economy. https://doi.org/10.1177/00346446211000821

Publisher's Note Springer Nature remains neutral with regard to jurisdictional claims in published maps and institutional affiliations. 